\title{
A fraction from Petiveria alliacea induces apoptosis via a mitochondria-dependent pathway and regulates HSP70 expression
}

\author{
Maria Claudia Cifuentes ${ }^{1}$, Diana Mercedes Castañeda ${ }^{1}$, Claudia Patricia Urueña ${ }^{1}$, Susana Fiorentino ${ }^{1 *}$ \\ ${ }^{1}$ Grupo de Inmunobiología y Biología Celular, Facultad de Ciencias, Pontificia Universidad Javeriana, Bogotá, Colombia. \\ *susana.fiorentino@javeriana.edu.co.
}

Received: 03-08-2009; Accepted: 10-11-2009

\begin{abstract}
Objective. To evaluate the biological activity of Petiveria alliacea extracts on tumoral cells in vitro. Materials and methods. P.alliacea fractions prepared by a bioguided purification protocol were characterized by their biological activities on two human tumoral cell lines. Morphological changes, cell viability, mitochondrial membrane depolarization, nuclear staining and activity on HSP70 were analyzed. Results. The present study demonstrates that P.alliacea fractions can induce apoptosis in a mitochondria-dependent pathway and down regulate HSP70 expression in vitro. The possible compounds present in P.alliacea responsible for the described biological activities were identified by dereplication methods. Conclusion. The present study provides new knowledge on the antitumoral properties of the plant species $P$. alliacea described in several ethnobotanical studies.
\end{abstract}

Key words: apoptosis; cancer; heat shock proteins; Petiveria alliacea.

\section{Resumen}

Una fracción de Petiveria alliacea induce apoptosis dependiente de la mitocondria y regula la expresión de la proteína HSP70. Objetivo. Evaluar la actividad biológica in vitro de extractos de Petiveria alliacea utilizando líneas celulares tumorales. Materiales y métodos. Las fracciones de P.alliacea fueron preparadas mediante un protocolo de purificación biodirigido. La actividad biológica fue caracterizada utilizando dos líneas celulares tumorales de origen humano, donde se analizaron los cambios morfológicos, la viabilidad celular, la actividad sobre la membrana mitocondrial y la fragmentación nuclear. Asimismo se evaluó la actividad de las fracciones sobre la expresión de la proteína HSP70. Resultados. El presente estudio muestra que las fracciones de P.alliacea inducen muerte celular por apoptosis dependiente de la mitocondria y además regulan negativamente la expresión de la proteína HSP70. Los compuestos que posiblemente son responsables de la actividad biológica presente en las fracciones de P.alliacea fueron identificados por dereplicación. Conclusión. El presente estudio contribuye a explicar en parte las propiedades antitumorales de la planta P.alliacea descritas en diversos escritos etnobotánicos.

Palabras claves: apoptosis; cáncer; proteínas de choque térmico; Petiveria alliacea.

* Maria Claudia Cifuentes and Diana Mercedes Castañeda contributed equally to this work. 


\begin{abstract}
Resumo
Uma fração de Petiveria alliacea induz apoptose dependente da mitocôndria e regula a expressão da proteína HSP70. Objetivo. Avaliar a atividade biológica in vitro de extratos de Petiveria alliacea utilizando linhagens de células tumorais. Materiais e métodos. Frações de P.alliacea foram preparadas utilizando um protocolo de purificação bio-dirigido. A atividade biológica foi caracterizada utilizando duas linhagens de células tumorais de origem humana, onde se analisaram as alterações morfológicas, a viabilidade celular, a atividade na membrana mitocondrial e a fragmentação nuclear. Também se avaliaram a atividade das frações sobre a expressão da proteína HSP70. Resultados. Este estudo mostra que as frações de P.alliacea induzem a morte celular por apoptose dependente da mitocôndria e também regulam negativamente a expressão da proteína HSP70. Os compostos que provavelmente são responsáveis pela atividade biológica presente nas frações de P.alliacea foram identificados por dereplicação. Conclusão. Este estudo ajuda a explicar, em parte, as propriedades antitumorais da planta P.alliacea descrita em vários escritos etnobotânicos
\end{abstract}

Palavras-chave: apoptose, câncer, proteínas de choque térmico; Petiveria alliacea

\section{Introduction}

Heat shock proteins (HSPs) are proteins whose expression is induced by different kinds of stresses. They exhibit strong cytoprotective properties and behave as molecular chaperones for other cellular proteins (1). There are several reports indicating that among the major inducible protein chaperones is heat shock protein 70 (HSP70). HSP70 is highly expressed in various human tumors especially of epithelial origin, and its over expression often correlates with an increase in cell proliferation, poor response to chemotherapy and reduced patient survival (2). Consequently, HSPs have become interesting targets for anticancer therapy. It has been shown that inhibition of HSP70 in tumor cells either by a gene knockout or by antisense agents enhances heat-induced radio sensitization (3). As a result there have been attempts to inhibit intracellular HSPs in order to facilitate cancer cell apoptosis or senescence. On the other hand, extracellular and membrane-associated HSPs have been used for cancer immunotherapy (4). Summing up, HSP70 has a dual effect: it can promote cancer development by suppressing cell death and favoring the expression of metastatic genes or can facilitate tumor rejection by the immune system (5). Also HSP70 protection may contribute to tumor mutation accumulation, and supports progress into more aggressive forms (6).

Hanagan in 2000 based in the fact that there are more than 100 distinct types of cancer and tumor subtypes within specific organs, proposed that the cancer phenotype is a manifestation of six essential alterations in cell physiology that collectively dictate malignant tumor growth. These six acquired capabilities are: self-sufficiency in growth signals, insensitivity to growth inhibitory signals, apoptosis evasion, limitless replicative potential, sustained angiogenesis, and tissue evasion and metastasis (7). These characteristics might be modulated by HSP70, particularly apoptosis cell death. Apoptosis is a well-defined programmed cell death (PCD), playing an important role in the development of biological systems and cell homeostasis. It is accompanied by a roundingup of the cell, retraction of pseudopodes, mitochondrial membrane depolarization, activation of flipase, plasma membrane blebbing, cell shrinkage, chromatin condensation, DNA fragmentation, nuclear disintegration, and formation of apoptotic bodies $(8,9)$. The search for natural products capable of regulating HSP70 expression becomes highly desirable because it can be used in cancer therapy to help decrease cancer cell resistance to apoptosis or to assist in antigen transference.

For decades, the phytochemical studies scope has been isolating compounds from biological resources, assigning the ethnobotanical properties of the whole plant to a single compound. However, Western medicine and even Ayurveda consider the possibility of a synergy between the components of the plant to be responsible for the biological activity. Furthermore, there are clear examples where a single isolated compound is unable to reproduce the plant extract activity (10). Recently, we have demonstrated that a more polar fraction from $P$. alliacea exerts several other functions, which include $\mathrm{G} 2$ cell cycle arrest as a result of cytoskeleton derangements leading to an apoptotic cell death through a mitochondria independent pathway. In addition, changes in the enzyme pool associated to glucose metabolism, could also mediate death from lack of nutrients (11). It is not likely to assume that a single compound may carry out all these multiple functions, suggesting that a standardized complex fraction might have more interesting antitumor activities in confronting tumor cells through different molecular targets. These observations are further supported by the fact that traditionally infusions and decoctions of this plant have been extensively used in some South American countries in leukemia and breast cancer patients (12). The present study evaluates the biological activity of a less polar $P$. alliacea fraction, chemically characterized and different from the previously reported, which induces tumoral cell death through mechanisms where mitochondria and 
HSP70 protein expression are implicated. These findings contribute to learn more about this plant activity, advancing in the study of standardized fractions with potential use in cancer treatment.

\section{Materials and methods}

\section{Plant material extraction}

The plant material was collected in Viotá, Cundinamarca, Colombia, and identified by Antonio Luis Mejía Piñeros (botanical consultant) as Petiveria alliacea L. by comparing the provided material with a sample from the National Colombian Herbarium, registry number 333406, August 12, 1991. P.alliacea dry ground leaves and stems $(3 \mathrm{~kg})$ were extracted in Soxhlet, with petroleum ether $(4 \mathrm{~L})$ for 48 hours. The plant extraction was continued with dichloromethane $\left(\mathrm{CH}_{2} \mathrm{Cl}_{2}\right)$, ethyl acetate (EtOAc), and $96 \%$ ethanol. All the extracts were filtered, concentrated under vacuum and exposed to biological assays. Of the four extracts, the one that maintained an effect on cell morphology and cytotoxicity was the ethyl acetate extract, and for the reason the extract was further investigated. The EtOAc extract was then flocculated with ethanol-water $(1: 1)$ at $65^{\circ} \mathrm{C}$ during $20 \mathrm{~min}$. The precipitated was discarded, and the supernatant recovered by filtration and subsequently fractionated in a silica gel G-60 column $(30 \times 4 \mathrm{~cm})$. The silica gel column was eluted with the following solvent ratios: $\mathrm{CH}_{2} \mathrm{Cl}_{2}-\mathrm{EtOAc}$ (7:3), and EtOAc and 96\% ethanol (1:1). Three fractions were obtained within the solvent proportion $\mathrm{CH}_{2} \mathrm{Cl}_{2}-\mathrm{EtOAc}$ (7:3), and TLC (Thin Layer Chromatography) was used to combine the eluted fractions. The fractions were labeled S1, $\mathrm{S} 2$, and S3, corresponding to the first, second and third eluates coming out from the column.

\section{Cell lines and culture conditions}

NB-4 (human myeloid leukemia) and K562 (human erythroleukemia) cells were obtained from our laboratory stocks. Cells were cultured in RPMI-1640 medium supplemented with $10 \%$ fetal bovine serum (FBS), $2 \mathrm{mM}$ L-glutamine, $100 \mathrm{U} / \mathrm{ml}$ penicillin, $100 \mu \mathrm{g} / \mathrm{ml}$ streptomycin and $0.01 \mathrm{M}$ Hepes and maintained at $37{ }^{\circ} \mathrm{C}$ with $5 \% \mathrm{CO}_{2}$ in humidified atmosphere. The cells were treated with $\mathrm{S} 1, \mathrm{~S} 2$ and $\mathrm{S} 3$ fractions at concentrations ranging from 7.8 to $125 \mu \mathrm{g} / \mathrm{mL}$ and plated (96 well plates). Ethanol or dimethyl sulfoxide (DMSO) $(0.2 \%)$ were used as vehicles.

\section{Cell viability and morphology}

Cells treated with $\mathrm{S} 1, \mathrm{~S} 2$ and S3 fractions (125 to $7.8 \mu \mathrm{g}$ / $\mathrm{ml}$ ) were plated on 96-well plates for morphological and cell viability (trypan blue) tests and observed under an inverted microscope (Olympus CH3). IC50 (50\% inhibition of cell growth) value was calculated using Minitab 14 Probit analysis (MINITAB ${ }^{\circledR}$ Release 14.1, Minitab Inc. 2003 Statistical Software).

\section{Mitochondrial membrane potential (MMP) measurement}

Cells $\left(3 \times 10^{5}\right)$ treated with S2 and S3 fractions during 4 and $8 \mathrm{~h}$, were stained with $10 \mu \mathrm{g} / \mathrm{ml}$ of JC-1 (lipophilic cationic probe 5,5',6,6'-tetrachloro-1,1',3,3'-tetraethylbenzimidazolcarbocyanine iodide, Sigma, St. Louis, MO), incubated for $10 \mathrm{~min}$ at $37^{\circ} \mathrm{C}$ and analyzed by flow cytometry (FACScalibur Cell Quest software Becton Dickinson, Fullerton, CA). Experiments were carried out by triplicate and results were expressed as a mean \pm SD. Positive control was P2Et, a highly purified gallic acid fraction from Caesalpinia spinosa.

\section{DNA fragmentation analysis}

Hematoxylin-eosine and DAPI (4',6-diamidino-2-phenylindole, Sigma) stained cells were monitored under microscope to evaluated the cell death type induced by the plant fraction. In brief, cells treated with S3 fraction for $24 \mathrm{~h}$ at $37^{\circ} \mathrm{C}$ under humidified atmosphere and $5 \% \mathrm{CO}_{2}$, were plated onto microscope slides by cytocentrifugation (Vybra cytospin, Japan) for $5 \mathrm{~min}$ at $500 \mathrm{rpm}$, fixed with ethanol and stained with hematoxylin ( $2 \mathrm{~min}$ ) and eosin (45 seconds). Excess dye was removed with ethanol (3 washes) and microscope slides were monitored and photographed under a light microscope (Olympus CH30, Japan) at a magnification of 100X. For DAPI staining, cells were plated on glass cover slides $(13 \mathrm{~mm} \varnothing)$ previously collagen-precoated $\left(6-10 \mu \mathrm{g} / \mathrm{cm}^{2}\right)$ at a density of $5 \times 10^{4}$ cells for $16 \mathrm{~h}$, and treated with $\mathrm{S} 3$ fraction at $37^{\circ} \mathrm{C}$ under humidified atmosphere and $5 \% \mathrm{CO}_{2}$ for $24 \mathrm{~h}$. Subsequently, cells were washed (PBS) and fixed with paraformaldehyde ( $2 \%$ in PBS) for $30 \mathrm{~min}$ at $4{ }^{\circ} \mathrm{C}$. After washing twice with PBS-BSA (1\%), cells were incubated in cold acetone (1 min); washed (1\% PBS-BSA) and incubated for 5 min with DAPI 300 nM (Sigma, St. Louis, MO). Slides with prolong antifade kit (Molecular Probes) were observed under a fluorescence microscope (Olympus, Japan).

\section{Mass spectra and UV chromatograms of S2 and S3 fractions}

HPLC-UV analysis was carried out on an Alliance 2795 (Waters ${ }^{\circledR}$ ) UK pump with a diode-array detector (DAD) and RP-C18 column ( $2.1 \times 150 \mathrm{~mm} 5 \mu \mathrm{m}$, Waters). Elution was performed using a solvent system comprising solvent A 
$\left(\mathrm{H}_{2} \mathrm{O}+1 \%\right.$ formic acid) and solvent $\mathrm{B}$ (methanol $+0.1 \%$ formic acid) mixed using a linear gradient starting with $60 \%$ A from 0 to $5 \mathrm{~min}$, decreasing to $0 \% \mathrm{~A}$ at $45 \mathrm{~min}$, and finally increasing to $60 \%$ A from 52 to $62 \mathrm{~min}$. Flow rate was set to $0.2 \mathrm{ml} / \mathrm{min}$, detection wavelength at $280 \mathrm{~nm}$ and UV spectra from 190-400 $\mathrm{nm}$. The mass spectra were acquired using a LCT TOF mass spectrometer (Micromass ${ }^{\circledR}, \mathrm{UK}$.) equipped with an ESI source in the negative and positive ion mode (Core facility, Natural Products Institute, CNRS, Gif-sur-Yvette, France).

\section{Heat shock and cell treatment with S2 and S3 fractions}

K562 cells incubated on 6-well plates ( $2 \times 10^{6}$ cells/well) in $3 \mathrm{ml}$ of supplemented medium were treated with $\mathrm{S} 3$ and $\mathrm{S} 2$ fraction $(6.2 \mu \mathrm{g} / \mathrm{ml})$ or quercetin and rutin $(100 \mu \mathrm{M}$, positive control). Treated cells were divided into two groups: one group was incubated at $37^{\circ} \mathrm{C}$ for $10 \mathrm{~h}$, subjected to heat shock $\left(42^{\circ} \mathrm{C}, 60 \mathrm{~min}\right)$ in a serological water bath, and then allowed to recover for $4 \mathrm{~h}$ at $37^{\circ} \mathrm{C}$; the other group was incubated for $15 \mathrm{~h}$ at $37^{\circ} \mathrm{C}$. During the entire procedure, both groups were maintained with S2 and S3 fraction or quercetin and rutin respectively.

\section{Protein separation and Western Blot (WB) analysis}

After treatment, cells were lysed using TDLB buffer (1 M Tris- $\mathrm{HCl} \mathrm{pH} 8,5 \mathrm{M} \mathrm{NaCl}, 20 \%$ sodium azide, $10 \% \mathrm{SDS}$, $10 \%$ NP40, 10\% sodium desoxicolate, 1\% PMSF) for $30 \mathrm{~min}$ at $4{ }^{\circ} \mathrm{C}$. Proteins were quantified by Bradford assay (BIORAD), separated by electrophoresis $(10 \%$ polyacrilamide gel) and transferred onto PVDF membranes.
Protein identification was accomplished using a monoclonal primary antibody anti-Hsp70 (Hsp70 clone 28348, kindly provided by Dr. Peter Van Endert INSERM Unit 580 Necker Hospital, Paris, France). For protein detection a super signal West Dura Extended Duration Substrate chemiluminescence kit (Pierce Lab) was used.

\section{Statistical analysis}

Comparison of the mean fluorescent intensity between samples and controls was carried out with an unpaired Student's $t$-test (GraphPad Prism, V 4.0). The results are expressed as mean \pm standard error (SEM) and $p<0.05$ implies significance.

\section{Results}

\section{Cytotoxicity}

The cytotoxic activity of the fraction was evaluated on cell lines K562 and NB4 as described in Materials and Methods. S2 and S3 fractions have a cytotoxic effect on both cell lines at a concentration of approximately $50 \mu \mathrm{g} / \mathrm{ml}$ (Table 1), a concentration considered as promising by the National Cancer Institute (NCI) of the United States (13). S1 fraction did not show any cytotoxic activity in any of the tested cell lines (data not shown), so further biological assays were carried out only with S2 and S3 fractions.

\section{Mitochondrial membrane depolarization induced by P.alliacea $\mathrm{S} 2$ and $\mathrm{S3}$ fractions}

In the screening for fractions with possible antitumor activity, an interesting trait to evaluate besides cytotoxicity is the

Table 1. IC50 values of different fractions over tumor cell lines. The values of tumor cell lines treated with P.alliacea fractions were calculated with Minitab 14 Statistical Software Probit analysis. The values are mean \pm SE from three independent experiments $(p<0.05)$.

\begin{tabular}{lll}
\hline Cell line/Treatment & K562 & NB4 \\
\hline S2 $(\mathrm{IC} 50 \mu \mathrm{g} / \mathrm{ml})$ & $37 \pm 1.7$ & $45 \pm 2.0$ \\
S3 $(\mathrm{IC} 50 \mu \mathrm{g} / \mathrm{ml})$ & $40.9 \pm 1.7$ & $43 \pm 2.1$ \\
DTS $(\mathrm{IC} 50 \mu \mathrm{g} / \mathrm{ml})$ & $2.1 \pm 0.5 *$ & $\mathrm{NT}$ \\
DBS $(\mathrm{IC} 50 \mu \mathrm{g} / \mathrm{ml})$ & $8.4 \pm 2.0 *$ & $\mathrm{NT}$ \\
Doxorrubicin $(\mathrm{IC} 50 \mu \mathrm{g} / \mathrm{ml})$ & $0.26 \pm 0.1 *$ & $\mathrm{NT}$ \\
\hline
\end{tabular}


type of cell death induced by the fraction. Mitochondria is one of the cell organelles well known to be involved in apoptotic cell death. Also a prominent cancer characteristic is apoptotic evasion through mitochondrial protection (7). Therefore, assessing the fraction effect on mitochondrial activity is a useful approach.

Mitochondrial membrane depolarization induced by S2 and S3 was previously evaluated at different concentrations with various cell lines in independent experiments (14). In all the cases, depolarization was dose-dependent and irreversible. Figure 1 summarizes the experimental results obtained using doses near the IC50 of S2 and S3 fractions. Mitochondrial membrane depolarization, evaluated with entire cells instead of isolated mitochondria, was clearly observed. Changes in membrane depolarization appear quite fast becoming irreversible after $8 \mathrm{~h}$ of treatment.

\section{P.alliacea $\mathrm{S} 2$ and $\mathrm{S3}$ fractions induced nuclear fragmentation}

Nuclear fragmentation can be used as an indication of apoptosis by observing the nuclei with fluorescent microscopy. To assess nuclear and cell morphology, NB4 cells treated with S2 and S3 fractions $(31.2 \mu \mathrm{g} / \mathrm{ml})$ for 4,8 and $24 \mathrm{~h}$ were stained with hematoxylin-eosin dye. Figure 2 shows the tumor cells with the negative control $(0.2 \%$ ethanol) in active mitosis indicating that there was no interference with the cell division, while treated nuclei show a clear nuclear fragmentation and chromatin condensation. S3 fraction causes nuclear fragmentation sooner (8h) than S2 fraction (24h). Once again, we observed that S3 fraction induces a quicker apoptosis cell death evidenced by the presence of nuclear fragments suggesting a coordinated DNA rupture. In our research S3 fraction is of great interest due to its high cytotoxicity and proven activity to
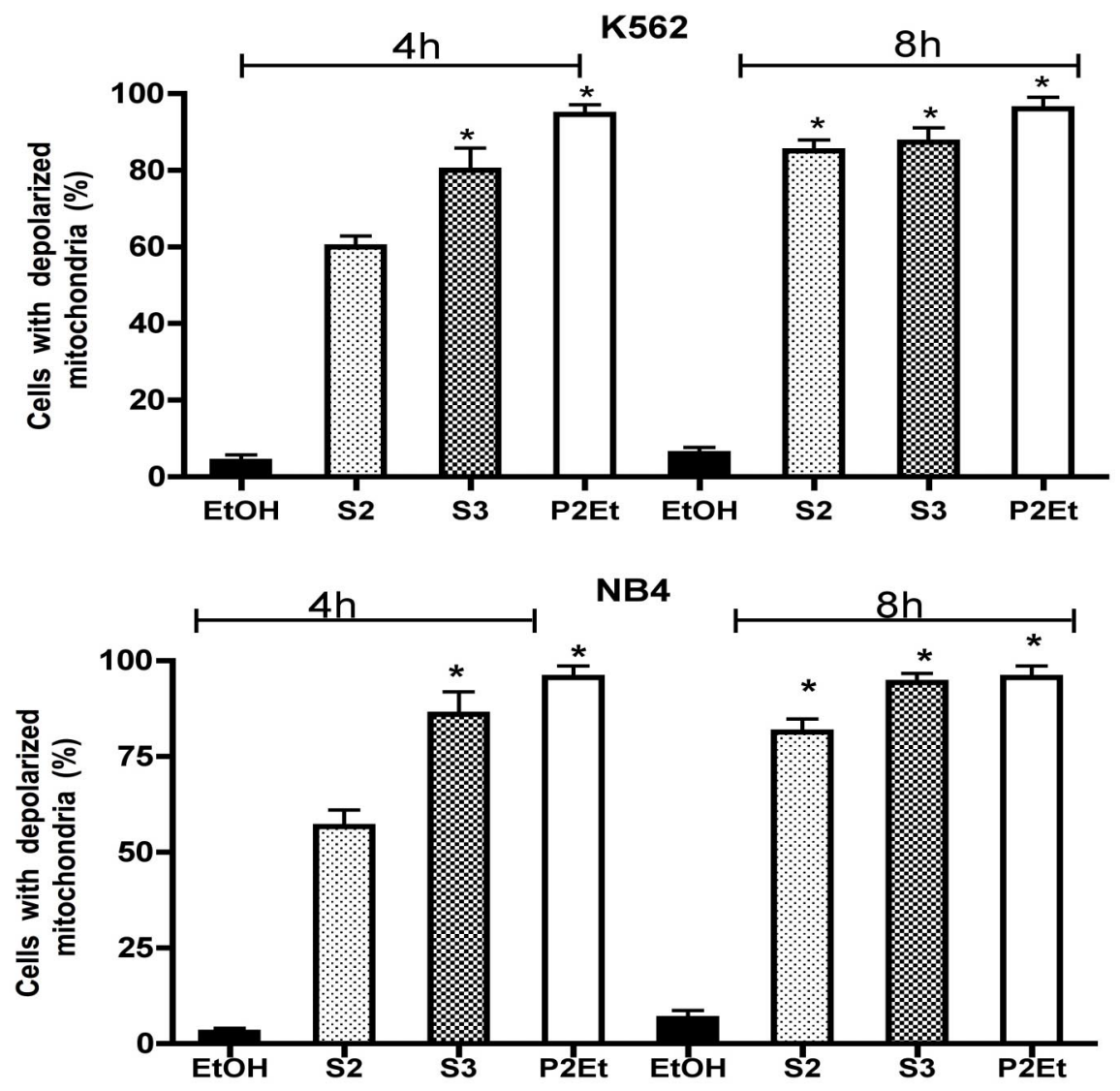

Figure 1. S2 and S3 fractions $(31.2 \mu \mathrm{g} / \mathrm{ml})$ induced mitochondrial membrane depolarization after 8 hours of treatment in different tumor cell lines. Cells were dyed with JC-1 (lipophilic dye) and analyzed by flow cytometry using the program Cell Quest Pro. Negative Control: ethanol. Positive Control: P2Et. Upper graph: K562 cell line; lower graph: NB4 cell line (N=3, $* \mathrm{p}<0.05)$. The values are mean \pm SE from 5 independent experiments $(\mathrm{p}<0.05)$. 
induce cell death by apoptosis over several cell lines. Figure 2 shows DNA fragmentation in A375 (human melanoma) cells evaluated by DAPI (E) after treatment with S3 fraction as compared to the control (D).

\section{P.alliacea fractions regulate intracellular HSP70 expression.}

To evaluate the activity of $P$.alliacea fractions on the HSP70 protein expression, K562 cells were exposed to heat shock and treated with $\mathrm{S} 2$ and S3 fractions at a dose 5 times less the IC50, in order to allow cell viability maintenance and observed changes in protein synthesis caused by the treatment. The HSP70 protein expression was evaluated by Western blot. Quercetin, a flavonoid well known to decrease HSP70 expression $(15,16)$ was used as a positive control. The activity shown by S3 fraction was very similar to quercetin, decreasing not only the heat stress inducible HSP70 protein expression (Figure $3 \mathrm{~A}, \mathrm{~B}$ ) but also its constitutive form (data not shown). The behavior exhibited by the $\mathrm{S} 2$ fraction under our experimental conditions was similar to that of rutin (quercetin glycoside), a compound known to increase the HSP70 level on the plasma
A

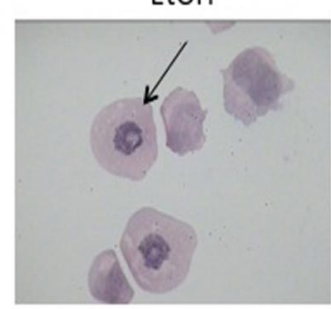

B

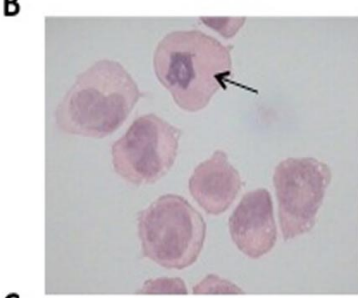

C

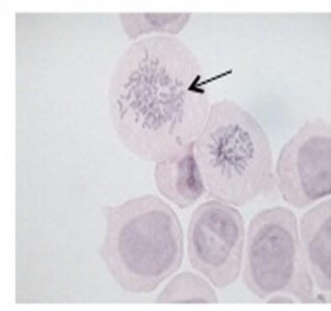

D

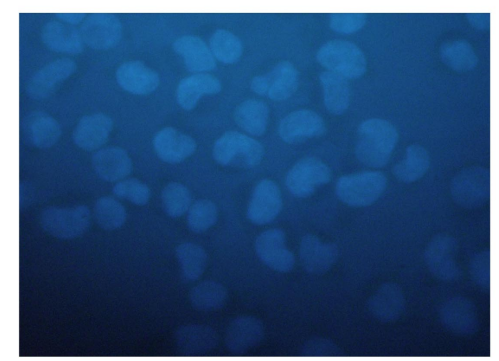

$\mathrm{S} 36.1 \mu \mathrm{g} / \mathrm{ml}$
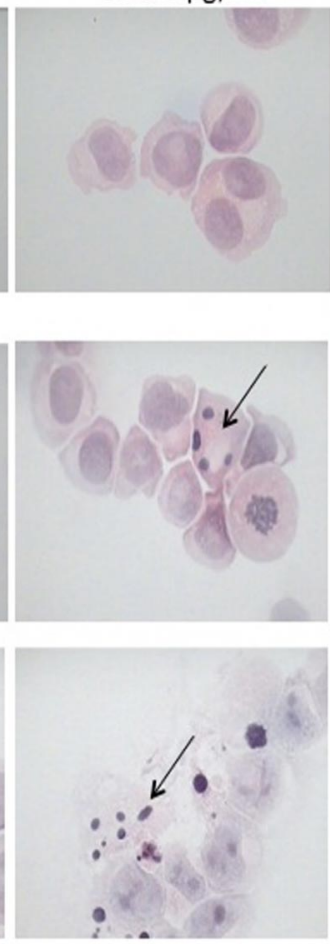

$E$

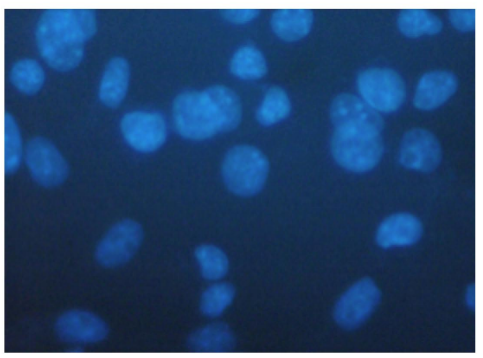

Figure 2. Treatment with S3 and S2 fraction induces apoptotic nuclei. For morphological analysis, NB4 cells treated for 4 (A), 8 (B), and 24 (C) hours with the plant fraction were cytospinned and stained with hematoxylin-eosin. Arrow indicates significant changes. (D) DAPI-stained A375 cells under Olympus fluorescence microscope (50X) with ethanol (vehicle) and (E) treated with $\mathrm{S} 3$ fraction $(31.2 \mu \mathrm{g} / \mathrm{mL})$ for $24 \mathrm{~h}$. 
membrane, rising tumor cell sensitivity to be lysed by NK cells (15).

The $\mathrm{S} 2$ fraction, as opposed to $\mathrm{S} 3$ fraction, seems to have little effect on inducible HSP70 expression, but in absence of thermal stress it is likely to induce an increase in protein expression (data not shown).

\section{Characterization of fractions $\mathbf{S 2}$ and $\mathbf{S 3}$}

Compound identification in the S2 and S3 fractions was carried out by comparing the mass/charge ratio $(\mathrm{m} / \mathrm{z})$ with previously reported compounds for the plant (1720 ). By matching up the $\mathrm{m} / \mathrm{z}$ ratio obtained from our chromatograms with the molecular masses reported in the literature, we were able to identify five compounds for S2 (corresponding to $28.3 \%$ of the detected compounds) and seven for S3 fraction (corresponding to $46.56 \%$ of the detected compounds), as shown in Table 2. Two peaks with the same $\mathrm{m} / \mathrm{z}$ ratio (314) but different retention times were assigned to the flavonoids leridol and petiveral, present in both fractions. Two peaks with an $\mathrm{m} / \mathrm{z}$ ratio of 298 and different retention times may correspond to leridal 7-demethyl and nonadecanoic acid, detected only in fraction $\mathrm{S} 2$. The $\mathrm{m} / \mathrm{z}$ ratios corresponding to 278 and
310 were assigned to dibenzyltrisulfide (DTS) and dibenzyltetrasulfide respectively, and present only in fraction $\mathrm{S} 3$. For ratio $\mathrm{m} / \mathrm{z}$ of 312 , present only in fraction $\mathrm{S} 3$, there were two flavonoids as possible candidates: leridal or leridal chalcone. Therefore, we did not discard the possibility of having both compounds present. Although the chromatography run was carried out up to 62 minutes for both fractions, ions formed did not suffice for an accurate mass assessment for compounds eluting after $35 \mathrm{~min}$ of running.

\section{Discussion}

P.alliacea has been widely commended for cancer treatment $(21,22)$, but the molecular mechanisms involving its antitumoral activity have not yet been clearly identified. The fractions S2 and S3 from P.alliacea have shown to decrease cell viability in a dose-dependent fashion, and to induce an early nonreversible mitochondrial membrane depolarization on human tumor cells lines K562 and NB4. Cell death associated with morphological changes and a coordinated DNA fragmentation suggest that both S2 and S3 fractions can induce apoptosis probably through the endogenous endonucleases downstream the mitochondria,
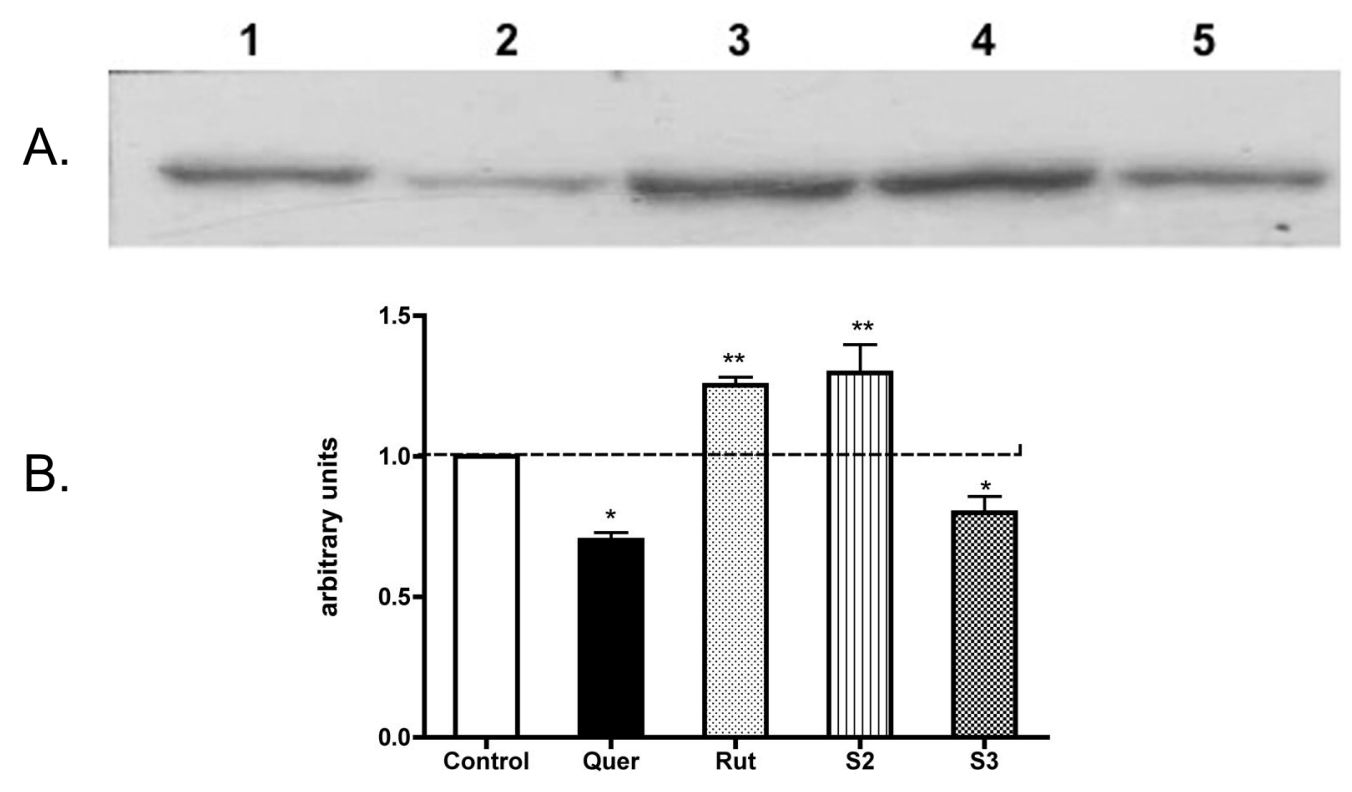

Figure 3. HSP70 modulation by S3 and S2 fraction on K562 cells. Cells treated for $10 \mathrm{~h}$, exposed to heat shock (42 $\left.{ }^{\circ} \mathrm{C}\right)$ for $1 \mathrm{~h}$, and $4 \mathrm{~h}$ of recovery at $37^{\circ} \mathrm{C}$. A. (1) Negative control (ethanol), (2) Control (100 $\mu \mathrm{M}$ quercetin), (3) Control (100 $\mu \mathrm{M}$ rutin), (4) S2 fraction $(6.2 \mu \mathrm{g} / \mathrm{ml}),(5) \mathrm{S} 3$ fraction $(6.2 \mu \mathrm{g} / \mathrm{ml})$. B. Density analysis was done with ImageJ program. Bar graph shows relative intensity in arbitrary units representing four independent experiments. Statistical analysis was carried out by comparing band intensities. Both $(*)$ and $(* *)$ indicate significant differences compared to the control $(\mathrm{p}>0.05)$. $(*)$ indicates statistical similarities between quercetin and S3 fraction, and (**) indicates statistical similarities between rutin and S2 fraction. 
Table 2. Compounds identified in S2 and S3 Petiveria alliacea fractions. Analysis was carried out by matching the $\mathrm{m} / \mathrm{z}$ ratio by dereplication with the MS spectra results. The peak area was used to calculate the percentage values corresponding to compound relative abundance in the fraction.

\begin{tabular}{lcc}
\hline Compound & S2 & S3 \\
& $(\mathbf{\%})$ & $(\mathbf{\% )}$ \\
\hline Petiveral & 15.4 & 21.7 \\
Leridol & 1.70 & 0.20 \\
S-Benzyl-cysteine sulfoxide & 1.80 & 0.30 \\
7-demethyl leridal & 6.40 & $\mathrm{nd}$ \\
Nonadecanoic acid & 3.00 & nd \\
Dibenzyl tetrasulfide & nd & 0.46 \\
Dibenzyl trisulfide & nd & 14.7 \\
Leridal or Leridal chalcone & nd & 9.20 \\
\hline
\end{tabular}

a mechanism currently under study in our laboratory. However, it is interesting to point out that S3 is likely to have a stronger induction of apoptosis than S2 fraction; nonetheless both fractions are capable of inducing cell death.

Heat shock proteins are a family of proteins well known to be involved in the regulation of cell survival, proliferation and protection against several types of stresses. Thermal stress amid other causes is known to increase their expression, as well as other external factors such as physical, chemical and oxidative stresses, cytostatic drugs, gamma and UV rays (23). Physiological events such as antigen presence (24), cellular growth, differentiation and aging may influence their expression (23). Several studies indicate that the over expression of inducible HSP70 promotes cancer development by suppressing various anticancer mechanisms like apoptosis and senescence, as well as facilitating the expression of metastatic genes (4). Accordingly, the down regulation of inducible HSP70 will facilitate apoptosis or senescence in cancer cells. Specific depletion of inducible HSP70 in cancer cells can be an important factor for cancer cell survival (25). S3 fraction has shown to decrease HSP70 expression after thermal stress (Figure 3), thus suggesting that it might be sensitizing tumor cells to die by apoptosis. It is well documented that HSP70 protein has dual effects: on one side, it promotes cancer development; and on the other side, it facilitates tumor rejection by the immune system $(5,23)$. Its expression as a membrane-bound protein and its extracellular occurrence represent an immunogenic potential, while the intracellular expression correlates with tumor development
(23). Conversely to the S3 fraction, S2 fraction does not decrease inducible HSP70; instead it seems to increase its expression with and without thermal stress (Figure 3 and data not shown). Under our experimental conditions, and in relation to HSP70 expression, S2 fraction maintains a similar behavior with rutin. The increase of HSP70 expression in tumor cells has been related to lysis sensitization by natural killer (NK) cells (26). It certainly will be of particular interest to study the relation between the use of these fractions and the lysis of tumor cell by NK cells. Within the compounds present in S3 but absent in S2 fraction are DTS, dibenzyltetrasulphide and leridal or leridal chalcone (Table 2). Despite the difference between fractions in compound composition, it would be inaccurate to state that DTS, dibenzyltetrasulphide, leridal or leridal chalcone are the only compounds responsible for the decrease in inducible HSP70 expression, or that their absence may increase its expression. Quercetin is a flavonoid that has long been recognized to inhibit HSP70 expression after heat shock, yet by an unknown mechanism (27). It has been proposed that quercetin inhibits the inducible HSP70 expression by inhibiting heat shock factor 1 (HSF1), or the association between HSF1 and the heat shock element (HSE) $(15,28)$.

From all the possible compounds responsible for the cytotoxic and apoptotic activities, we propose that DTS could be the compound involved. Several reports describe the anti-proliferative and cytotoxic activity of DTS on a wide range of cancer cell lines $(29,30)$. Moreover, in 2008 Urueña et al. reported that $P$. alliacea fractions containing 
DTS also induced changes in the cytoskeleton proteins and influenced the cell proliferation machinery. The relation between the activities exerted by the fractions on the cytoskeleton and on the expression of HSPs needs to be further investigated. S-benzyl-cysteine sulfoxide is another compound shared by both fractions and a nonvolatile precursor of a series of sulphur compounds produced by degradation during plant extraction. It has been reported to exhibit antimicrobial and antifungal properties as well as a possible antitumoral activity (31).

Therefore, it is essential to study the different biological activities reported in the present study for all the compounds in the fractions, in order to determine their functional and biological specificity.

Ethnopharmacological reports have widely described P.alliacea as a plant exhibiting antitumoral and immunostimulatory properties, among others. The present study contributes to partly explain these activities. In relation to the use of plant fractions with biological activities as the ones described in the present study, it is interesting to point out that the observed activities are only reproducible when the fraction is kept at $4^{\circ} \mathrm{C}$, light protected and for a period of time no longer than a year. Activities due to the presence of DTS can be lost, given the volatility of the compound, which is not detected in the mixtures after several months of storage. Therefore, it is also necessary to evaluate the chemical stability of compounds of each fraction and search for agents allowing longer storage periods.

\section{Conclusion}

Herein, we demonstrated that fractions S2 and S3 induce apoptosis by the mitochondrial pathway, but their activities differ: S2 upregulates while S3 downregulates the HSP70 expression. The use of a complex fraction (S3) able to negatively modulate the expression of HSP70 protein may be an interesting alternative for antitumor therapy, increasing tumor cells sensitization to death by apoptosis, or else by increasing HSP70 (S2) to render tumor cells more responsive to NK cytotoxicity.

We consider that compounds as DTS, S-benzyl-cysteine sulfoxide, leridal, leridal chalcone, dibenzyl tetrasulfide, leridol and petiveral work in a synergistic mode conferring the described biological behavior. Currently, we are working on the isolation of all the S3 fraction compounds and assessment of their biological activities in isolation and in fixed combinations.

\section{Financial support}

Financial support was provided by the Instituto Colombiano para el Desarrollo de la Ciencia y la Tecnologia "Francisco José de Caldas" (COLCIENCIAS), Bogotá, Colombia (grant No. 12030514660), the Terry Fox Foundation and the Instituto Nacional de Cancerología, Bogotá, Colombia (contract No. 02-03/2005).

\section{Competing interests}

The authors declare that they have no competing interests.

\section{References}

1. Jäättelä M. Escaping cell death: Survival proteins in cancer. Experimental Cell Research 1999; 248: 3043.

2. Garrido C, Brunet M, Didelot C, Zermati Y, Schmitt E, Kroemer G. Heat shock proteins 27 and 70: antiapoptotic proteins with tumorigenic properties. Cell Cycle 2006; 5: 2592-2601.

3. Hunt CR, Dix DJ, Sharma GG, Pandita RK, Gupta A, Funk M, Pandita TK. Genomic instability and enhanced radiosensitivity in Hsp70.1- and Hsp70.3-deficient mice. Molecular Cell Biology 2004; 24: 899-911.

4. Sherman M, Multhoff G. Heat Shock Proteins in Cancer. Annals of New York Academy of Sciences 2007; 1113: 192-201.

5. Fiorentino S, Barreto A, Castañeda D, Cifuentes C. Anti-Tumor Response and Heat Shock Proteins (HSP): A friend or foe relationship?. In Asea AA, De Maio A. Heat shock proteins potent mediator of inflammation and immunity. Springer publisher. Dordrecht, Netherlands. 2007, 321-336p.

6. Sarto C, Binz P, Mocarelli P. Heat shock proteins in human cancer. Electrophoresis 2000; 21: 1218-1226.

7. Hanahan D, Weinberg RA. The hallmarks of cancer. Cell 2000; 100(1): 57-70.

8. Bouchier-Hayes L, Lartigue L, Newmeyer DD. Mitochondria: pharmacological manipulation of cell death. Journal of Clinical Investigation 2005; 115: 26402647. 
9. Hengartner MO. The biochemistry of apoptosis. $\mathrm{Na}$ ture 2000; 407: 770-783.

10. Williamson E. Synergy and other interactions in phytomedicines. Phytomedicine 2001; 8: 401-409.

11. Urueña C, Cifuentes C, Castañeda D, Arango A, Kaur P, Asea A, Fiorentino S. Petiveria alliacea extracts uses multiple mechanisms to inhibit growth of human and mouse tumoral cells. BMC Complement Alternative Medicine 2008; 8: 60.

12. Malpezzi EL, Davino SC, Costa LV, Freitas JC, Giesbrecht AM, Roque NF. Antimitotic action of extracts of Petiveria alliacea on sea urchin egg development. Brazilian Journal of Medical and Biological Research 1994; 27(3): 749-754.

13. Boyd M. The NCI in Vitro Anticancer Drug Discovery Screen. Concept, implementation and operation, 19851995. In Anticancer Drug Development Guide Preclinical Screening. ClinicalTrials and Approval. Teicher B. Ed Humana Press. Totowa, NJ.1997, 23-42.

14. Castañeda D. Evaluación de la actividad inductora de apoptosis de los extractos obtenidos a partir de Petiveria alliacea sobre líneas de células tumorales. Tesis de grado de Microbiología Industrial, 2006. Universidad Javeriana, Bogotá.

15. Wang RE, Kao JL, Hilliard CA, Pandita RK, Roti Roti JL, Hunt CR, Taylor JS. Inhibition of heat shock induction of heat shock protein 70 and enhancement of heat shock protein 27 phosphorylation by quercetin derivatives. Journal of Medicinal Chemistry 2009; 52(2): 1912-1921.

16. Ramos AA, Lima CF, Pereira ML, Fernandes-Ferreira M, Pereira-Wilson C. Antigenotoxic effects of quercetin, rutin and ursolic acid on HepG2 cells: Evaluation by the comet assay. Toxicology Letters 2008; 177 : 66-73.

17. Kubec R, Musah RA. Cysteine sulfoxide derivatives in Petiveria alliacea. Phytochemistry 2001; 58(6): 981985 .

18. Benevides PJ, Young MC, Giesbrecht AM, Roque NF, Bolzani VS. Antifungal polysulphides from Petiveria alliacea L. Phytochemistry 2001; 57(5): 743-747.

19. Delle Monache F, Cuca LE. Petiveria alliacea II: Further Flavonoids and Triterpenes, Gazzeta Chimica Italiana 1996; 126: 275-277.

20. De Sousa JR, Demuner AJ, Pinheiro JA, Breitmaier E, Cassels BK. Dibenzyl trisulphide and trans-N-methyl- 4-methoxyproline from Petiveria alliacea. Phytochemistry 1990; 29(11): 3653- 3655.

21. Correa JR, Bernal H. Especies Vegetales Promisorias de Paises del convenio Andrés Bello. SECAB Editor. Bogotá, Colombia.1998

22. Gupta MP. 270 Plantas medicinales Iberoamericanas. Primera edicion. Convenio Andres Bello y Subprograma X del CYTED. Bogotá, Colombia. 1995, 617p.

23. Multhoff G. Heat shock protein 70 (Hsp70): Membrane location, export and immunological relevance. Methods 2007; 43: 229-237.

24. Calderwood SK, Khaleque MA, Sawyer DB, Ciocca DR. Heat shock proteins in cancer: chaperones of tumorigenesis. Trends in Biochemical Sciences 2006; 31(3): 164-172.

25. Nylandsted J, Brand K, Jäättelä M. Heat shock protein 70 is required for the survival of cancer cells. Annals of New York Academy of Sciences 2000; 926: 122-125.

26. Dedoussis GV, Kaliora AC, Andrikopoulos NK. Effect of phenols on natural killer (NK) cell-mediated death in the K562 human leukemic cell line. Cell Biology International 2005; 11: 884-889.

27. Zanini C, Giribaldi G, Mandili G, Carta F, Crescenzio N, Bisaro B, Doria A, Foglia L, di Montezemolo LC, Timeus F, Turrini F. Inhibition of heat shock proteins (HSP) expression by quercetin and differential doxorubicin sensitization in neuroblastoma and Ewing's sarcoma cell lines. Journal of Neurochemistry 2007; 103: $1344-1354$.

28. Hansen RK, Oesterreich S, Lemieux P, Sarge KD, Fuqua S. Quercetin inhibits heat shock protein induction but not heat shock factor DNA-binding in human breast carcinoma cells. Biochemistry and Biophysical Research 1997; 239: 851-856.

29. Williams LA, Rosner H, Levy HG, Barton EN. A critical review of the therapeutic potential of dibenzyl trisulphide isolated from Petiveria alliacea L (guinea hen weed, anamu). West Indian Medical Journal 2007; 56(1): 17-21.

30. An H, Zhu J, Wang X, Xu X. Synthesis and anti-tumor evaluation of new trisulfide derivatives. Bioorganic and Medicinal Chemistry Letters 2006; 16: 48264829 .

31. Kim S, Kubec R, Musah RA. Antibacterial and antifungal activity of sulfur-containing compounds from Petiveria alliacea L. Journal of Ethnopharmacology 2006; 104: 188-192. 